Archives of Agriculture and Environmental Science

\title{
Optimization of nitrogen requirement for better growth and yield of brinjal (Solanum melongena L.)
}

\section{Shaila Sharmin* (iD and Lutfor Rahman}

College of Agricultural Sciences, International University of Business Agriculture and Technology, Uttara Model Town, Dhaka-1230, BANGLADESH

"Corresponding author's E-mail: shaila.sharmin@iubat.edu

\section{ARTICLE HISTORY}

Received: 03 February 2019

Revised received: 27 February 2019

Accepted: 02 March 2019

\section{Keywords}

Brinjal (S. melongena)

Growth and yield

Optimization

Nitrogenous fertilizer

\begin{abstract}
A field experiment was conducted at the College of Agriculture Sciences, Agriculture Research Field of International University of Business Agriculture and Technology (IUBAT), Uttara, Dhaka, to optimize nitrogen requirements for growth and yield response of brinjal ( $S$. melongena). There were six treatments of urea viz., 0, 275, 300, 325, 350 and $375 \mathrm{~kg} \mathrm{ha}^{-1}$ and the experiment was laid out in randomized complete block design (RCBD) with four replications. The texture of the experimental soil was sandy loam and fertility status was very low. Parameters measured include: plant height, number of leaves plant ${ }^{-1}$, leaf area, number of branches plant ${ }^{-1}$, number of flower clustersplant ${ }^{-1}$, number of flowersplant ${ }^{-1}$, fruit diameter, fruits length, number of fruitsplant ${ }^{-1}$, fruit weight and yield. Present study results revealed that application of the highest dose of urea showed positive significant influence on growth and reproductive characters of brinjal (S. melongena). Similarly, yield and yield contributing characters of brinjal ( $S$. melongena) increased with the increasing rates of urea. The highest yield (18.0 ton ha ${ }^{-1}$ ) was obtained from the application of $375 \mathrm{~kg} \mathrm{ha}^{-1}$ urea, while the lowest yield (10.1 ton ha ${ }^{-1}$ ) was found from the control treatment. Thus, the overall study results suggested that $375 \mathrm{~kg} \mathrm{ha}^{-1}$ urea performed the best in context Agriculture Research Field soils of IUBAT, Uttara, Dhaka. The study concluded that before final recommendation of the application dose, further study is needed in different agro-ecological zones of Bangladesh.
\end{abstract}

(C)2019 Agriculture and Environmental Science Academy

Citation of this article: Sharmin, S. and Rahman, L. (2019). Optimization of nitrogen requirement for better growth and yield of brinjal (Solanum melongena L.). Archives of Agriculture and Environmental Science, 4(1): 33-38, https://dx.doi.org/10.26832/24566632.2019.040105

INTRODUCTION

Eggplant or brinjal (S. melongena) is a native crop of subtropical areas of south-eastern Asia and was introduced into Europe by early Arab traders. It is a member of the Solanaceae family. It has been widely grown in southern Europe, the Middle East, Africa and Asia for hundreds of years (Ullio, 2003). It is a long duration vegetable crop with high yield which removes large quantities of different nutrient elements from the soil. Brinjal (S. melongena) is familiar throughout the world for its low calories and high mineral contents, which is beneficial for human health. It is rich source of potassium, sodium, magnesium, calcium and iron (Kowalski et al., 2003; Raigón et al., 2008) as well as dietary fiber (Sanchez-Castillo et al., 1999). It is consumed almost on a regu- larly basis by the both rural and urban peoples of Bangladesh. Brinjal (S. melongena) is the second most important vegetable crop in Bangladesh in respect of acreage and production (BBS, 2018). It is cultivated all over the country in two seasons viz. rabi and kharif. In 2016-17, it is cultivated in 80195 and 45665 acres of land with an annual production of 347541 and 159891 tons in rabi and kharif seasons, respectively (BBS, 2018). But average yield of the crop in Bangladesh is very low compared to those obtained in some advanced countries of the world. The low yield of brinjal (S. melongena) in Bangladesh is primarily due to the lack of high yielding varieties, inadequate and imbalanced use of manure and fertilizers especially the nitrogenous ones. As because nitrogen is the most deficient nutrient element in the soils of Bangladesh. Thus brinjal (S. melongena) requires a large 
quantity of nitrogenous fertilizer for its proper growth, development and yield (Aminifard et al., 2010).

In Bangladesh, the farmers use huge amount of different chemical fertilizers injudiciously for crop production especially for vegetables and among that urea is the top most. Nitrogenous fertilizer often have mobility in soils, which leads to soil pollution and ground water contamination, ultimately causing health hazards to the people (Begum et al., 2014; Giannakoula et al., 2010). Therefore, management of nitrogen fertilizers such as rate, type and application time is very important (DePascale et al., 2006). Nutritional stress is one of the main factors limiting crop productivity; this may occur due to an excess or a deficit of nutrients (Souza et al., 2018). Thus, judicious application of nitrogenous fertilizer with appropriate rate is essential. Considering this fact, the study was planned to optimize nitrogen requirement for cultivation of brinjal (S. melongena) at Agriculture Research Field condition of International University of Business Agriculture and Technology, Uttara, Dhaka.

\section{MATERIALS AND METHODS}

\section{Experimental site}

The experiment was conducted at the Agriculture Research Field of International University of Business Agriculture and Technology, 4 Embankment Drive Road, Sector 10, Uttara Model Town, Dhaka 1230, Bangladesh during the period from May 10 to Aug 10, 2016 in Kharif season. Geographically the experimental field is located at $23.8883^{\circ} \mathrm{N}$ latitude and $90.3909^{\circ} \mathrm{E}$ longitude. The experiment was set up on the medium high land in an open and sunny area. The texture of the soil was sandy loam and the $\mathrm{pH}$ was 7.6. The climate of the area is characterized by high temperature and medium rainfall with an annual rainfall of 119-145 cm during April to August and little or no rainfall during September to March.

\section{Treatments and layout}

There were six treatments of urea viz. $T_{0}$ (control), $T_{1}(275 \mathrm{~kg}$ $\left.\mathrm{ha}^{-1}\right), \mathrm{T}_{2}\left(300 \mathrm{~kg} \mathrm{ha}^{-1}\right), \mathrm{T}_{3}\left(325 \mathrm{~kg} \mathrm{ha}^{-1}\right), \mathrm{T}_{4}\left(350 \mathrm{~kg} \mathrm{ha}^{-1}\right)$ and $\mathrm{T}_{5}$ $\left(375 \mathrm{~kg} \mathrm{ha}^{-1}\right)$. Urea was applied to the plot in three equal splits at 20,40 and 60 days after transplanting. The experiment was laid out as randomized complete block design (RCBD). The experimental area is divided into 4 blocks representing the 4 replications and each replication was divided into 6 plots which were equal in size i.e. $0.25 \mathrm{~m}^{2}(0.5 \mathrm{~m} \times 0.5 \mathrm{~m})$. Thus, total number of plots was $24(6 \times 4)$. Within each replication, 6 plots were assigned with six nitrogen (urea) treatments which were randomly distributed. There were $40 \mathrm{~cm}$ and $30 \mathrm{~cm}$ gaps from block to block and plot to plot for intercultural operations, respectively (Figure 1).

\section{Application of fertilizers}

Fertilizers applied in the plots as recommended for high yield goal and very low soil fertility status as described in Fertilizer Recommendation Guide (FRG, 2012). The recommended doses of phosphorus, potassium, sulphur, zinc and cow dung were 42 , 105, 18, $2.5 \mathrm{~kg} \mathrm{ha}^{-1}$ and 5 ton ha ${ }^{-1}$, respectively. Nutrient elements were applied from triple superphosphate (TSP), muriate of potash (MoP), gypsum and zinc sulphate fertilizers, respectively. Potassium was applied in three equal splits at 20 , 40 and 60 days after transplanting along with the treatments of urea as mentioned in FRG (2012).

\section{Test crop and intercultural operations}

Brinjal (S. melongena) variety BARI Begun-8 was used for the experiment. Seeds of this variety were collected from the Horticulture Division of Bangladesh Agriculture Research Institute, Joydebpur, Gazipur. After collection, seedlings were grown in pots and then 30 days old brinjal (S. melongena) seedlings were transplanted on the experimental field. Intercultural operations viz. weeding, irrigation, disease and pest management were done using traditional methods as and when necessary. Sex pheromone trap was used in the experimental field for controlling brinjal shoot and fruit borer.

\section{Data collection and processing}

Data on growth, yield and yield contributing characters were recorded from each plot and total yield was calculated through average plant yield by multiplying plant population. Then collected data were analyzed statistically using Minitab 17.

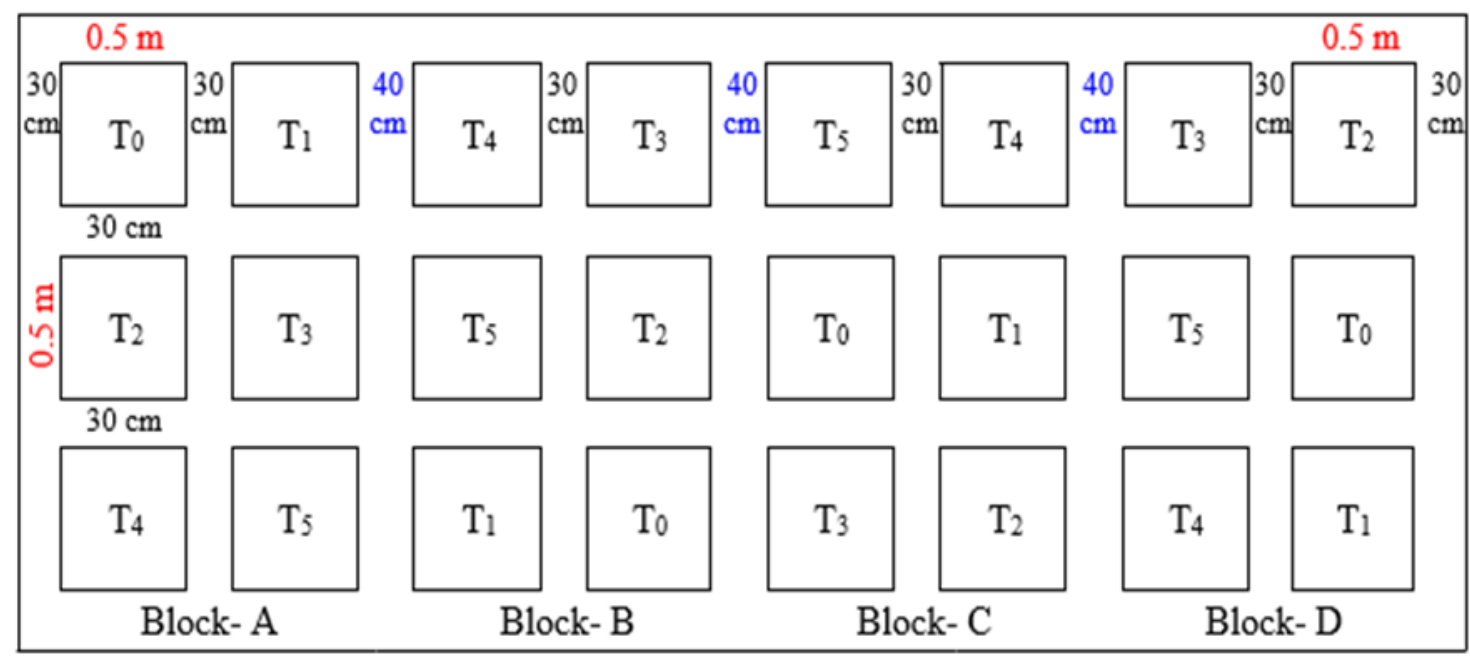

Figure 1. Experimental design and layout. 


\section{RESULTS AND DISCUSSION}

Effect of nitrogen on different growth parameters of brinjal Plant height of brinjal (S. melongena) varied significantly among the different treatments of nitrogen. The tallest plant was found from $\mathrm{T}_{1}$ treatment $(47.50 \mathrm{~cm})$ at 20 DAT, but at 40 and 60 DAT the highest plant heights were obtained from $T_{5}$ treatment (80.08 and $87.08 \mathrm{~cm}$, respectively). On the other hand, the smallest plants were found from control treatment both at 20 and 60 DAT ( 37.50 and $68.25 \mathrm{~cm}$, respectively) but at 40 DAT the minimum plant height was obtained from $\mathrm{T}_{4}$ treatment $(61.89 \mathrm{~cm})$. It can be inferred from Figure 2 that at later stage of growth (i.e. 60 DAT) nitrogen levels showed remarkable change in plant height compared to the initial stage of growth of brinjal ( $S$. melongena). This result is in agreement with Wange and Kale (2004) who reported that significant improvement in plant height of eggplant occurred due to over recommended rate of nitrogenous fertilizers. Similarly, increase in plant height with increasing level of fertilizer application; have been reported by Bar-Tal et al. (2001) and Prabhu et al. (2003). Ge et al. (2008) observed that nitrogen application increased plant height at vegetative, flowering and reproductive stages. Devi et al. (2002) reported better growth of brinjal (S. melongena) by the application of $260 \mathrm{~kg}$ $\mathrm{ha}^{-1}$ urea. Hussain et al. (2009) reported plant height of brinjal



Figure 2. Effect of different levels of nitrogen on plant height of brinjal (S. melongena) at different days after transplanting.

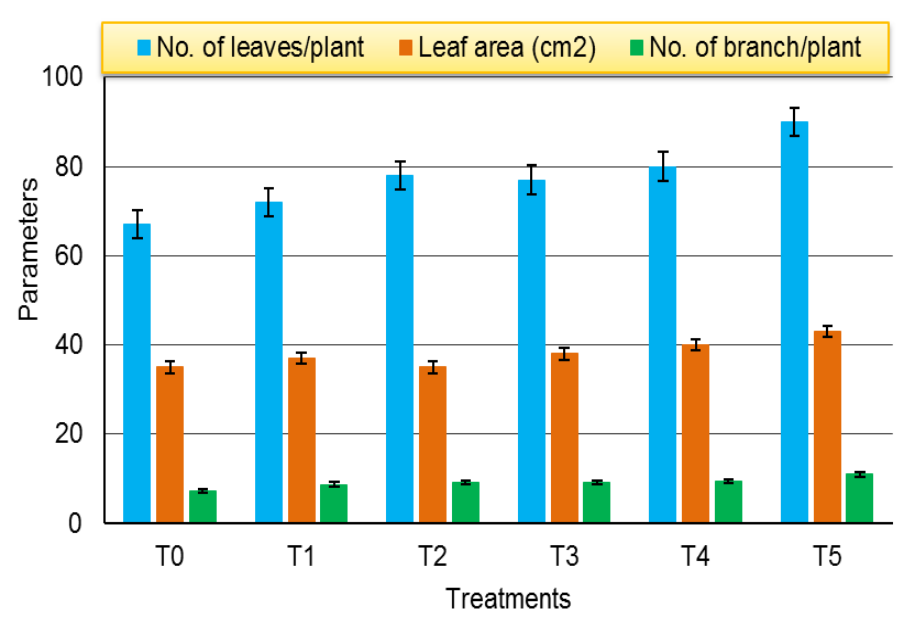

Figure 3. Effect of different levels of nitrogen on different growth parameters of brinjal (S. melongena).
(S. melongena) at harvesting varied from $115.2-131.0 \mathrm{~cm}$ by the application of different types of nitrogenous fertilizers.

The application of different levels of nitrogen significantly affected the number of leaves plant ${ }^{-1}$, leaf area and number of branches plant ${ }^{-1}$ of brinjal (S. melongena) (Figure 3 ). The maximum number of leaves plant ${ }^{-1}(90)$ was found from $T_{5}$ treatment while the minimum (67) was obtained from $T_{0}$ treatment at 60 DAT (Figure 3). Thus it can be inferred from this result that brinjal (S. melongena) required higher amount of nitrogen for its better growth and development. Similar result was also stated by Wange and Kale (2004), and they reported that over recommended rate of nitrogenous fertilizer significantly increased number of leaves in eggplant. Jilani et al. (2008) stated that application of nitrogen at the rate of $150 \mathrm{~kg} \mathrm{ha}^{-1}$ increased number of leaves of brinjal (S. melongena). Mohammad et al. (2010) stated that nitrogen is found to promote growth and increases biomass production, and nitrogen fertilization has been used to increase growth of eggplants.

Effect of different levels of nitrogen on leaf area of brinjal ( $S$. melongena) was statistically significant at $1 \%$ level of probability. The maximum leaf area was obtained from the treatment $T_{5}$ $\left(43.0 \mathrm{~cm}^{2}\right)$, while the minimum was found from the control treatment $\left(35.0 \mathrm{~cm}^{2}\right)$. The increase in leaf area index could be attributed to increased cell division and elongation resulting in increased leaf expansion, more numbers of leaves due to beneficial influence of additional nitrogen. This result is at par with the report published by Kumar et al. (2018). The highest number of branches plant ${ }^{-1}$ (11.00) was also found from the $T_{5}$ treatment and the lowest (7.33) was obtained from $T_{0}$ treatment at 60 DAT. Present study results revealed that application of the highest dose of urea showed positive influence to increase leaf area and total number of branches of brinjal (S. melongena). Takebe et al. (1995) reported that increments in the leaf dry weight may be due to a combination of nitrogen with plant matter produced during photosynthesis. Hussain et al. (2009) reported number of branches plant $^{-1}$ of brinjal (S. melongena) varied from $11.96-15.64$ by the application of different types of nitrogenous fertilizers. Tanko and Yusuf (2015) reported that the highest numbers of branches were found at all the sampling stages of brinjal (S. melongena) when 200 $\mathrm{kgN} \mathrm{ha}^{-1}$ of fertilizer was applied.

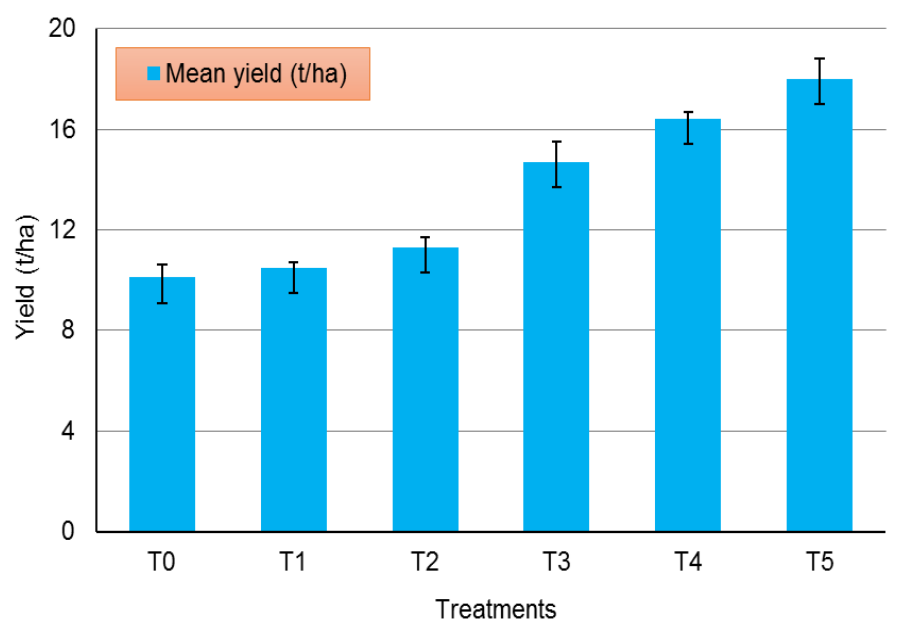

Figure 4. Effect of different levels of nitrogen on yield of brinjal (S. melongena). 
Effect of nitrogen on reproductive and yield characteristics of brinjal

Effect of different levels of nitrogen on number of flower cluster plant $^{-1}$, number of flowers plant ${ }^{-1}$, number of fruits plant ${ }^{-1}$, fruit length and fruit weight of brinjal (S. melongena) were statistically significant at $1 \%$ level of probability, while the fruit diameter was significant at $5 \%$ level of probability (Table 1 ).

The maximum number of flower cluster plant ${ }^{-1}$ (12.33) was recorded from the treatment $\mathrm{T}_{4}$, which was statistically at par with the treatment $T_{5}$. On the other hand, the minimum number of flower cluster plant ${ }^{-1}$ (7.25) was obtained from the treatment $T_{1}$. Similarly, the highest number of flowers plant ${ }^{-1}$ (17.05) was found from the $T_{5}$ treatment but the lowest number of flowers plant $^{-1}$ (11.25) was found from the control treatment. The present study results illustrate that the significant highest mean values of number of flowers plant ${ }^{-1}$ was obtained by application of urea at the rate of $375 \mathrm{~kg} \mathrm{ha}^{-1}$. This result is in agreement with the report of Mirdad (2011), who stated that the eggplant plants responded well to fertilization by using high levels of nitrogen, and gave the most favorable performances for all studied characters.

The application of different levels of nitrogen significantly affected the numbers of fruits plant ${ }^{-1}$ and fruit length of brinjal (S. melongena) (Table 1). The highest numbers of fruits plant ${ }^{-1}$ and fruit length (10.00 and $25.05 \mathrm{~cm}$, respectively) was recorded from the highest dose of urea (i.e. $T_{5}$ treatment) while the lowest numbers of fruits plant ${ }^{-1}$ and fruit length (6.33 and 20.25 $\mathrm{cm}$, respectively) was obtained from the control treatment. It is apparent from Table 1 that numbers of fruits plant ${ }^{-1}$ and fruit length of brinjal ( $S$. melongena) increased with the increasing rates of nitrogen. Thus, it can be inferred from the present study that the productivity of brinjal (S. melongena) is highly responsive to the additional added nitrogen. Furthermore, it has been reported that a sufficient supply of various nitrogenous compounds is required in each plant cell for its proper functioning (Mengel and Kirkby, 1987). On the other hand, fruit diameter and fruit weight of brinjal (S. melongena) ranged from 5.75$8.10 \mathrm{~cm}$ and $78.00-98.05 \mathrm{~g}$, respectively, and the highest fruit diameter and weight were recorded from the $\mathrm{T}_{5}$ treatment. This result is concomitant with Aujla et al. (2007) who also reported that increasing the rate of nitrogen fertilizer increased the average fruit weight and fruit volume. Similarly, Mirdad (2011) reported that increasing the application of nitrogen to the grown plants, irrespective of the used amount up to $300 \mathrm{~kg} \mathrm{~N}$ $\mathrm{ha}^{-1}$, significantly increased all reproductive and yield components of brinjal (S. melongena). Akanbi et al. (2007) reported that nitrogen fertilizer affected seed number, fruit $\mathrm{pH}$, crude protein, total solid and ascorbic acid of eggplant and nitrogen deficiencies reduced both physical and chemical properties of fruits.

\section{Effect of nitrogen on yield of brinjal}

The application of different levels of nitrogen significantly affected the yield of brinjal (S. melongena). The highest yield (18.0 ton $\mathrm{ha}^{-1}$ ) was obtained from the application of $\mathrm{T}_{5}$ treatment, while the lowest yield (10.1 ton $\mathrm{ha}^{-1}$ ) was found from the control treatment (Figure 4). It is apparent from Figure 4 that similar to different yield contributing characters, yield of brinjal (S. melongena) increased with the increasing rates of urea. Thus, it can be inferred from the present study that the productivity of brinjal (S. melongena) is highly responsive to the additional added nitrogen. The response of additional nitrogen may be due to the fact that plant produce more leaves would have increased photosynthetic area and hence better performance in terms of yield. This result is in agreement with Wange and Kale (2004) who reported that significant improvement in yield (74\%) of eggplant occurred due to over recommended rate of $\mathrm{N}$ fertilizer. Pal et al. (2002) reported that eggplant fruit yield increased with increase in nitrogen up to $187.5 \mathrm{~kg} \mathrm{ha}^{-1}$. Results concerning the fruits yield of brinjal ( $S$. melongena) obtained by the present study, are in general agreement with the reports published by Mirdad (2011) and Aujla et al. (2007), and they also revealed that fruits yield increased significantly with increasing nitrogen levels. Similar observation was also reported by Mohammad et al. (2010), who stated that nitrogen is found to promote growth and increases biomass production, and nitrogen fertilization has been used to increase growth and yield of eggplant. On the other hand, Devi et al.(2002) found better fruit girth, fruit weight and fruit yield level of eggplant with the application of $120 \mathrm{~kg} \mathrm{Nha}^{-1}$.

Table 1. Effect of different levels of nitrogen on reproductive and yield characteristics of brinjal (S. melongena).

\begin{tabular}{|c|c|c|c|c|c|c|}
\hline Treatment & $\begin{array}{l}\text { No. of flower } \\
\text { cluster plant }^{-1}\end{array}$ & $\begin{array}{l}\text { No. of flowers } \\
\text { plant }^{-1}\end{array}$ & $\begin{array}{l}\text { No. of fruits } \\
\text { plant }^{-1}\end{array}$ & $\begin{array}{l}\text { Fruit length } \\
\qquad(\mathrm{cm})\end{array}$ & $\begin{array}{l}\text { Fruit diameter } \\
\qquad(\mathrm{cm})\end{array}$ & $\begin{array}{l}\text { Fruit weight } \\
\text { (g) }\end{array}$ \\
\hline $\mathrm{T}_{0}$ & 8.10 & 11.25 & 6.33 & 20.25 & 6.00 & 78.00 \\
\hline $\mathrm{T}_{1}$ & 7.25 & 13.00 & 6.50 & 21.33 & 5.75 & 80.10 \\
\hline $\mathrm{T}_{2}$ & 7.50 & 12.75 & 7.00 & 21.50 & 6.05 & 81.33 \\
\hline $\mathrm{T}_{3}$ & 10.05 & 14.00 & 7.25 & 22.05 & 6.50 & 84.67 \\
\hline $\mathrm{T}_{4}$ & 12.33 & 16.10 & 9.33 & 23.10 & 7.00 & 83.33 \\
\hline $\mathrm{T}_{5}$ & 12.25 & 17.05 & 10.00 & 25.05 & 8.10 & 98.05 \\
\hline CV (\%) & 6.70 & 6.80 & 6.15 & 4.26 & 6.49 & 2.85 \\
\hline SE (mean) & 0.67 & 0.53 & 0.43 & 0.63 & 0.31 & 1.40 \\
\hline Level of significance & $* *$ & $* *$ & $* *$ & $* *$ & * & $* *$ \\
\hline
\end{tabular}

${ }^{* *}=$ Significant at $1 \%$ level of probability; ${ }^{*}=$ Significant at $5 \%$ level of probability. 
Conclusion

This investigation concluded that the brinjal (S. melongena) fruit yield and yield contributing characters showed significant positive influence with the increasing rates of urea. The highest fruit yield of brinjal (S. melongena) was recorded from the application of $375 \mathrm{~kg} \mathrm{ha}^{-1}$ urea, while the lowest yield was found from the control treatment. Hence, the present study results suggested that $375 \mathrm{~kg} \mathrm{ha}^{-1}$ urea performed the best in context Agriculture Research Field soils of IUBAT, Uttara, Dhaka. However, fertilizer recommendation in future should be site, location and variety specific. The study finally concluded that before final optimization of the application dose, further study is needed in different seasons and agro-ecological zones of Bangladesh.

Open Access: This is an open access article distributed under the terms of the Creative Commons Attribution 4.0 License, which permits unrestricted use, distribution, and reproduction in any medium, provided the original author(s) if the sources are credited.

\section{REFERENCES}

Akanbi, W.B., Togun, A.O., Olaniran, O.A., Akinfasoye, J.O. and Tairu, F.M. (2007). Physico-chemical properties of eggplant (Solanum melongena L.) fruit in response to nitrogen fertilizer and fruit size. Agricultural Journal, 2(1): 140-148, $\quad$ http://medwelljournals.com/abstract/? doi=aj.2007.140.148

Aminifard, M.H., Aroiee, H., Fatemi, H., Ameri, A. and Karimpour, S. (2010). Responses of eggplant (Solanum melongena L.) to different rates of nitrogen under field conditions. Journal of Central European Agriculture, 11(4): 453-458, https://doi.org/10.5513/JCEA01/11.4.863

Aujla, M.S., Thind, H.S. and Buttar G.S. (2007). Fruit yield and water use efficiency of eggplant (Solanum melongena L.) as influenced by different quantities of nitrogen and water applied through drip and furrow irrigation. Journal of Science and Horticulture, 112:142-148, http://agris.fao.org/ agris-search/search.do?recordID=US201300767970

Bar-Tal, A., Aloni, B., Karni, L. and Rosenberg, R. (2001). Nitrogen nutrition of greenhouse pepper: Effects of nitrogen concentration and $\mathrm{NO}_{3}: \mathrm{NH}_{4}$ ratio on growth, transpiration, and nutrient uptake. HortScience, 36(7): 1252-1259, https:// pdfs.semanticscholar.org/9a03/83577c5c1f98512623549 bb4c1fb1f365348.pdf

BBS (Bangladesh Bureau of Statistics) (2018). Yearbook of Agricultural Statistics-2017. 29 ${ }^{\text {th }}$ Series. Statistics and Informatics Division, Ministry of Planning, Government of the People's Republic of Bangladesh. Retrieved from www.bbs.gov.bd

Begum, K., Mohiuddin, K.M., Zakir, H.M., Rahman, M.M. and Hasan, M.N. (2014). Heavy metal pollution and major nutrient elements assessment in the soils of Bogra city in Bangladesh. Canadian Chemical Transaction, 2(3): 316-326. https://doi.org/10.13179/canchemtrans.2014.02.03.0088
DePascale, S., Tamburrino, R., Maggio, A., Barbieri, G., Fogliano, B. and Pernice, R. (2006). Effect of nitrogen fertilization on the nutritional value of organically and conventionally grown tomatoes. Acta Horticulturae, 700: 107-110, https://doi.org/10.17660/ActaHortic.2006.700.14

Devi, H.H., Maity, T.K., Paria, N.C. and Thapa, U. (2002). Response of brinjal to different sources of nitrogen. Journal of Vegetable Sciences, 29(1): 45-47.

FRG, Fertilizer Recommendation Guide (2012). Bangladesh Agricultural Research Council (BARC), Farmgate, Dhaka-1215. Retrieved from www.barc.gov.bd

Ge, T., Song, S., Chi, M., Huang, D. and Iwasaki, K. (2008). Effects of nitrogen forms on carbon and nitrogen accumulation in tomato seedling. Agricultural Sciences in China, 7(11): 13081317, https://doi.org/10.1016/S1671-2927(08)60179-0

Giannakoula, A., Moustakas, M., Syros, T. and Yupsanis, T. (2010). Aluminum stress induces up-regulation of an efficient antioxidant system in the Al-tolerant maize line but not in the Al- sensitive line. Environmental and Experimental Botany, 67(3): 487-494, https://doi.org/10.1016/j.envexpbot.2009.07.010

Hussain, M.J., Ali, M.Y., Rahman, M.M., Quayyum, M.A. and Choudhury, D.A. (2009). Brinjal (Solanum melongena) fruit yield in response to urea super granule application. The Agriculturists, 7(1\&2): 6-11.

Jilani, M.S., Faheem, M.F. and Waseem, K. (2008). Effect of different nitrogen levels on growth and yield of brinjal (Solanum melongena L.). Journal of Agricultural Research, 46 (3): 245-251, http://agris.fao.org/agris-search/search.do? recordID=PK2009000131

Kowalski, R., Kowralska, G. and Wiercinski, J. (2003). Chemical composition of fruits of three eggplant (Solanum melongena, L.) cultivars. Folia Horticulturae, 15(2): 89-95.

Kumar, D.A., Sivakumar, K. and Mariyappan, E. (2018). Comparative studies on the growth and yield of brinjal (Solanum melongena, L.) var. PLR 2 based on bioinoculants and inorganic fertilizers. International Journal of Research and Scientific Innovation, V(III): 191-193, https://www.rsisinternational.org/journals/ijrsi/digitallibrary/volume-5-issue-3/191-193.pdf

Mengel, K. and Kirkby, E.A. (1987). Principle of Plants Nutrition. $4^{\text {th }}$ Edition, International Potash Institute. Pern. Switzerland. pp. 687.

Mirdad, Z.M. (2011). Vegetative growth yield and yield components of eggplant (Solanum melongena, L.) as influenced by irrigation intervals and nitrogen levels. JKAU: Meteorology, Environment and Arid Land Agriculture Sciences, 22(1): 31-49, https://www.kau.edu.sa/Files/320/ Researches/59417_29758.pdf

Mohammad, H.A., Hossein, A., Hamide, F., Atefe, A. and Sajede, K. (2010). Responses of eggplant (Solanum melongena L.) to different rates of nitrogen under field conditions. Journal of Central European Agriculture, 11(4): 453-458.

Pal, S., Saimbhi, M.S. and Bal, S.S. (2002). Effect of nitrogen and phosphorus level on growth and yield of brinjal hybrid 
(Solanum melongena L.). Journal of Vegetable Science, 29: 90-91.

Prabhu, M., Veeraragavathatham, D. and Srinivasa, K. (2003). Effect of nitrogen and phosphorous on growth and yield of brinjal. South Indian Horticulture, 51(1/6): 152-156.

Raigón, M.D., Prohens, J., Muñoz-Falcón, J.E. and Nuez, F. (2008). Comparison of eggplant landraces and commercial varieties for fruit content of phenolics, minerals, dry matter and protein. Journal of Food Composition and Analysis, 21(5): 370-376, https://doi.org/10.1016/j.jfca.2008.03.006

Sanchez Castillo, C.P., Englyst, H.N., Hudson, G.J., Lara, J.J., Solano, M.L., Munguía, J.L. and James, W.P. (1999). The non -starch polysaccharide content of Mexican foods. Journal of Food Composition and Analysis, 12(4): 293-314.

Souza, Á.H.C., Rezende, R., Lorenzoni, M.Z., Seron, C.C. and Santos, F.A.S. (2018). Agronomic efficiency and growth of eggplant crop under different potassium and nitrogen doses. Revista Caatinga, 31(3): 737-747, https://dx.doi.org/10.1590/1983-21252018v31n324rc
Takebe, M., Ishihara, T., Matsuna, K., Fojimoto, J. and Yoneyama, T.M. (1995). Effect of nitrogen application on the contents of sugars, ascorbic acid, nitrate and oxalic acid in spinach (Spinacia oleracea L.) and komatsuna (Brasica campestris L.). Japanese Journal of Soil Science and Plant Nutrition, 66: 238246, https://doi.org/10.20710/dojo.66.3_238

Tanko, U.M. and Yusuf, M.J. (2015). Influence of N-fertilizer application on the yield and yield components of two varieties of eggplant (Solanum melongena L.) in Anyigba, Kogi State. Journal of Biology, Agriculture and Healthcare, 5(17): 201-208, https://www.iiste.org/Journals/index.php/JBAH/ article/viewFile/25651/26519

Ullio, L. (2003). Eggplant Growing. Agfact H8.1.29, $3^{\text {rd }}$ Edition. NSW Agriculture, Australia. 1-4 pp. Retrieved from www.agric.nsw.gov.au

Wange, S.S. and Kale, R.H. (2004). Effect of bio fertilizers and nitrogen levels on brinjal crop. Journal of Soils and Crops, 14 (1): 9-11. 